\title{
Jolantos Bagdzevičienès dizainas dviejų laikotarpių kontekste
}

\section{Rasa Janulevičiūtè}

Vilniaus dailès akademija

Maironio g. 6, LT-01124 Vilnius

rasa.januleviciute@vda.lt

Straipsnyje apžvelgiama produktyvios, ekspozicijų dizainą, buitinius baldus ir baldus reprezentaciniams interjerams kūrusios, tačiau iki šiol mažai analizuotos dizainerès Jolantos Bagdzevičienès kūrybinè biografija. Nagrinėjami jos sukurti projektai, kurie aprėpia du laikotarpius - sovietini ir atkurtos nepriklausomybès. Analizė grindžiama pačios dizainerės prisiminimais, jos asmeninio archyvo medžiaga.

Reikšminiai žodžiai: dizainas, Baldų projektavimo konstravimo biuras, Lietuvos architektų sajunga. 
Jolanta Bagdzevičienė - Lietuvos dizaino kūrèja, Lietuvos architektų sajungos narè, ịvertinta dizaino parodose ir konkursuose „Lietuviški baldai“, „Baldai“, Lietuvos pramonininku konfederacijos „Lietuvos metu gaminys “1. Jos reikšmė Lietuvos dizaino istorijai neabejotina, tačiau iki šiol atidesnio žvilgsnio į jos darbus nebūta. Todèl šio tyrimo tikslas - apžvelgti ir akademinei bendruomenei bei plačiajai visuomenei pristatyti pernelyg mažai žinomos lietuvių dizainerès Jolantos Bagdzevičienès kūrybinị kelią, aptarti jos sukurtus projektus parodant tiek išlikusius, tiek ir realizuotus, bet mūsų dienų nepasiekusius gaminius.

Informacijos apie Jolantos Bagdzevičienès dizainą pateikta Vytauto Beigos pradètoje ir Vilijos Gerulaitienès bei Eugenijaus Algimanto Gūzo baigtoje rengti knygoje Lietuvišku baldu dizaino kūrèjai 195\%-1990: Baldu projektavimo konstravimo biuras - profesionalios veiklos židinys, kuri, deja, yra vienintelis susistemintas apžvalginio pobūdžio tyrimų šaltinis, pagal rengèjų anonsą, išties tapęs svariu kultūrinị paveldą liudijančiu dokumentu². Šiame leidinyje yra publikuotas ir Bagdzevičienės straipsnis, kuriame ji prisiminė savo kelią dizaino link, sovietinio laikotarpio ypatumus, dizaino iššūkius Lietuvai laisvejjant ir atkurtos nepriklausomybės metu. Apie šios dizainerès kèdžių projektus rašyta atliekant Šiaulių baldų gamybiniame susivienijime „Venta“ ypač masiškai gamintos vadinamosios „norvegiškos“ kėdès tyrimą̧. Visgi paminèti šaltiniai apie lietuviškų baldų kūrèjus ir kita informacija apie Bagdzevičienę yra fragmentiška ${ }^{5}$. Turèta medžiaga neatskleidžia jos kūrybinių inspiracijų ir galutinio rezultato esmès, todèl pagrindiniu šio tyrimo šaltiniu tapo pokalbiai su dizainere, jos asmeninis archyvas $^{6}$.

1 Bagdevičienès kūrybinės biografijos faktai pateikti: Lietuvišku baldu dizaino kūrèjai 195\%-1990: Baldu projektavimo konstravimo biuras - profesionalios veiklos židinys, sud. Vytautas Beiga, Vilija Gerulaitienė ir Eugenijus Gūzas (Vilnius: Mokslo ir enciklopedijų leidybos centras, 2013), 142-157.

2 Ibid., 224.

3 Jolanta Bagdzevičienė, „Visus projektus koreguoja gyvenimas“, in Lietuvišku baldu dizaino kūrèjai 1957-1990: Baldų projektavimo konstravimo biuras-profesionalios veiklos židinys, 210-211.

4 Rasa Janulevičiūtè, 10 kèdžių: Lietuvos dizaino naratyvai (Vilnius: Vilniaus dailès akademijos leidykla, 2018), 412-421.

5 Kai kuriuose šaltiniuose skelbiama dizainerès pavardè. Pvz., Lietuvos banko leidinyje apie Lietuvos banko rūmus Vilniuje paminèta, kad, 1994-1997 m. pritaikant Totorių g. 4 patalpas banko veiklai, Jolanta Bagdzevičienè suprojektavo baldus valgyklai, posėdžių salèms, kabinetams. Žr. Lietuvos banko rūmai Vilniuje, teksto autorė Morta Baužienė (Vilnius: Lietuvos bankas, 2007), 33.

6 Straipsnio autorès pokalbiai su Bagdzevičiene vyko 2018-2020 metais. Pokalbių medžiaga saugoma asmeniniame straipsnio autorès archyve. 
Bagdzevičienės profesionalus kūrybinis kelias prasidèjo 8 deš. pradžioje. 1972 m. ji pradèjo studijuoti architektūrą Vilniaus inžinerinio statybos instituto (VISI, dab. Vilniaus Gedimino technikos universitetas, VGTU) Architektūros fakultete. Jos baigiamajam darbui „Jaunimo pramogų rūmai Šeškinëje“ vadovavo architektas, tuo metu docentas Arnas Dineika. Bagdzevičienės asmeniniame archyve išsaugota baigiamojo darbo, rankomis pagaminto gynimui modernaus, universalaus kultūros ir sporto centro maketo, nuotrauka. Naują požiūrị i architektūrą rodo suprojektuoto pastato proporcijos, karkasinė ažūrinių lubų struktūra. Jaunimo pramogų rūmų komplekse suprojektuota sfera su joje numatytu baseinu liudija, kad vadinamujų „fuleristų“, sąmoningai arba netiesiogiai patyrusių JAV architekto ir dizainerio, geodezinio kupolo autoriaus Richardo Buckminsterio Fullerio ittaką, buvo ne tik tarp rusu, bet ir tarp lietuviu architektų?. Baigiamajị darbą Badzevičienė apgynè sẻkmingai, tad galèjo dirbti ne pagal paskyrimą, kaip buvo ịprasta sovietmečiu, o darbovietę pasirinkti.

Diplomuota architektė norèjo projektuoti baldus, todèl $1977 \mathrm{~m}$. ìsidarbino svarbiausioje sovietmečiu Lietuvos baldų projektavimo įstaigoje Baldụ projektavimo konstravimo biure (toliau - Baldų PKB) [1 il.], kuriame buvo susitelkusios geriausių Lietuvos kūrèjų, tuomet projektuotojų konstruotojų, dabar sakytume - dizainerių, pajėgos. Biure dirbo Vytautas Beiga, Brigita Adomonienė, Lygija Marija Kislauskaitė-Stapulionienė, Algimantas Stapulionis, Valerija Ema Cukermanienė, Eugenijus Antanas Cukermanas, Liucija Zaveckienė ir kiti Lietuvos dizaino meistrai. Bagdzevičienė prisimena menišką ịstaigos atmosferą:

Lietuvių ekspoziciją projektavau 1979-aisiais, kai visa Maskva ruošėsi 1980-ujjų Olimpiadai. Vieną kuriozą iki šiol pamenu. I Liaudies ūkio pasiekimų parodų

7 Architektūros istorikè Ana Bronovickaja (Анна Броновицкая) paskaitoje apie Richardo Buckminsterio Fullerio kūrybą minėjo, kad po JAV nacionalinès parodos, surengtos 1959 m. Sokolnikų parke Maskvoje, kurioje buvo sukonstruotas Fullerio kupolas, geodezinio kupolo idèja labai greitai pasklido tarp Sovietų Sajungos architektų. Autorė pateikia pavyzdį: „1959 m., kai vyko JAV paroda Sokolnikuose, Maskvos pionierių rūmų projektas jau buvo iš esmès baigtas, vyko statyba. Ir tie maži kupolai virš žiemos sodo atsirado jau po amerikiečių parodos, ir aišku, kad tai - geodeziniai Fullerio kupolai." Sparčią Fullerio išradimo sklaidą Sovietų Sajungoje ir jo pritaikymą pačioms įvairiausioms reikmėms - nuo grūdų saugyklų iki pionierių stovyklų paviljonų - paskatino jo sąsajos su rusų architektais, kelionès į Sovietų Sajungą, kurių metu Fulleris pasakojo apie savo idèjas. Sovietiniuose žurnaluose pasirodė publikacijų, kuriose buvo šlovinami sovietinių architektų ,atradimai“ - geodeziniai kupolai, nors iš tiesų tai, pasak autorès, buvo banaliausia vagystė. Анна Броновицкая, „Бакминстер Фуллер (США, 1895-1983)“, in Музей современного искусства „,Гараж“, https://www.youtube.com/wat ch?v=5rXJAoOAEuk\&list=PLRSwFqRepg4FLjYNn77DKTROti-0kjZ_e\&index=7. 


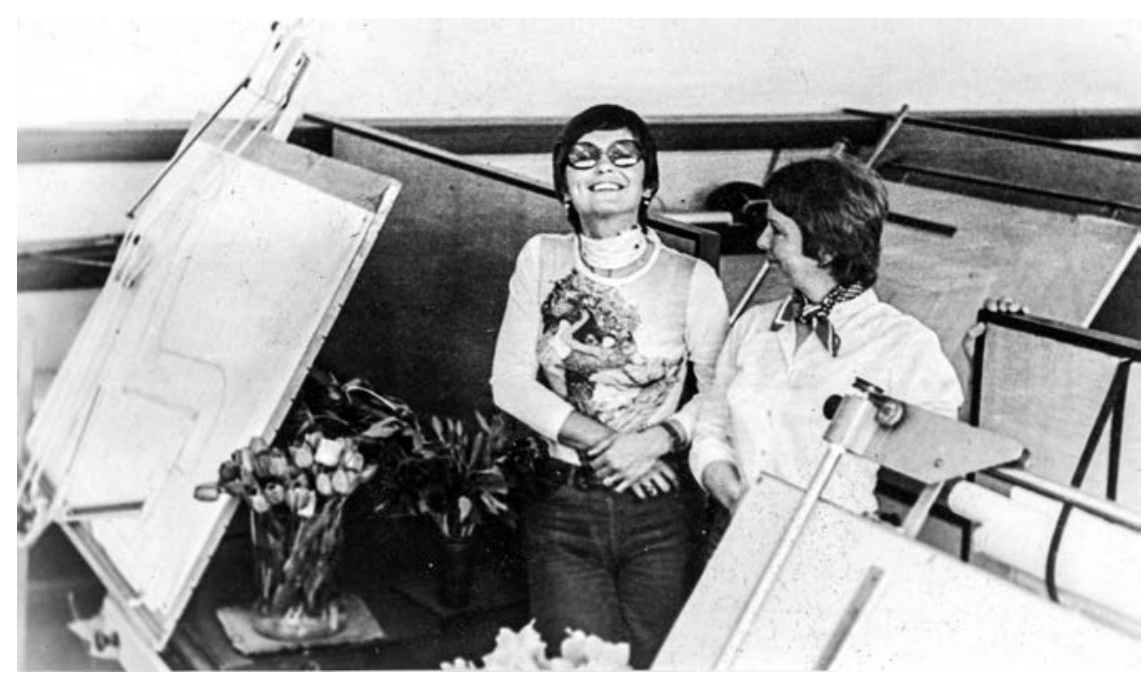

1.

Architektès Jolanta Bagdzevičienė (kairèje) ir Dalia Architects Jolanta Bagdzevičienè (left) and Dalia Siaurusaitienė Baldụ projektavimo konstravimo biure, nuotrauka iš asmeninio J. Bagdzevičienès archyvo

paviljoną atvežè kilimą, bet ne tos spalvos. Sienoms jau buvo užsakyti puikūs, balti prancūziški tapetai. Nusprendžiau baltais tapetais ne tik sienas dekoruoti, bet ir klijuoti ant grindụ vietoj nederančio kilimo. Man besidarbuojant priejjo parodos kuratorius. Pamatè, ką darau, bet nieko nesakè. Prieš kiekvienos parodos atidarymą pirmiausia pražygiuodavo komisija, kurioje būdavo aukšti valdžios, ministerijų atstovai. Tikrindavo, ar viskas gerai. Kaip šiandien prisimenu: stoviu netoliese ir girdžiu, kaip tas pats kuratorius, atsivedęs komisiją, sako: „Vot, sumašedšaja litovka sdelala belyj pol“ („Štai, pakvaišusi lietuvè išklojo grindis baltai.“ - red.). Tuo tarpu solidus ministerijos atstovas atrèžè: „Ras sdelala, značet, tak i nado“(,Jeigu padarè, vadinasi, taip reikia.“ - red.). Lietuviu profesionalumu tuomet niekas neabejojo, lygiavosi ir gerbė. Buvome kviečiami projektuoti sudètingiausius projektus visoje Tarybų Sajungoje. ${ }^{8}$

Baldu projektavimo Bagdzevičienė nestudijavo, tad teko išmokti visko nuo pradžių. Tai nebuvo neįveikiama užduotis, nes, pasak dizainerès, „baldas artimas mažajai architektūrai konstrukcijos prasme, juk stalas

8 Šis Bagdzevičienės prisiminimas yra išspausdintas knygoje Lietuvišku baldu dizaino kürèjai 195\%-1990: Baldu projektavimo konstravimo biuras - profesionalios veiklos židinys, 210. Jos pageidavimu čia publikuojamas pakartotinai. Iš Bagdzevičienės laiško autorei, 20201003. 


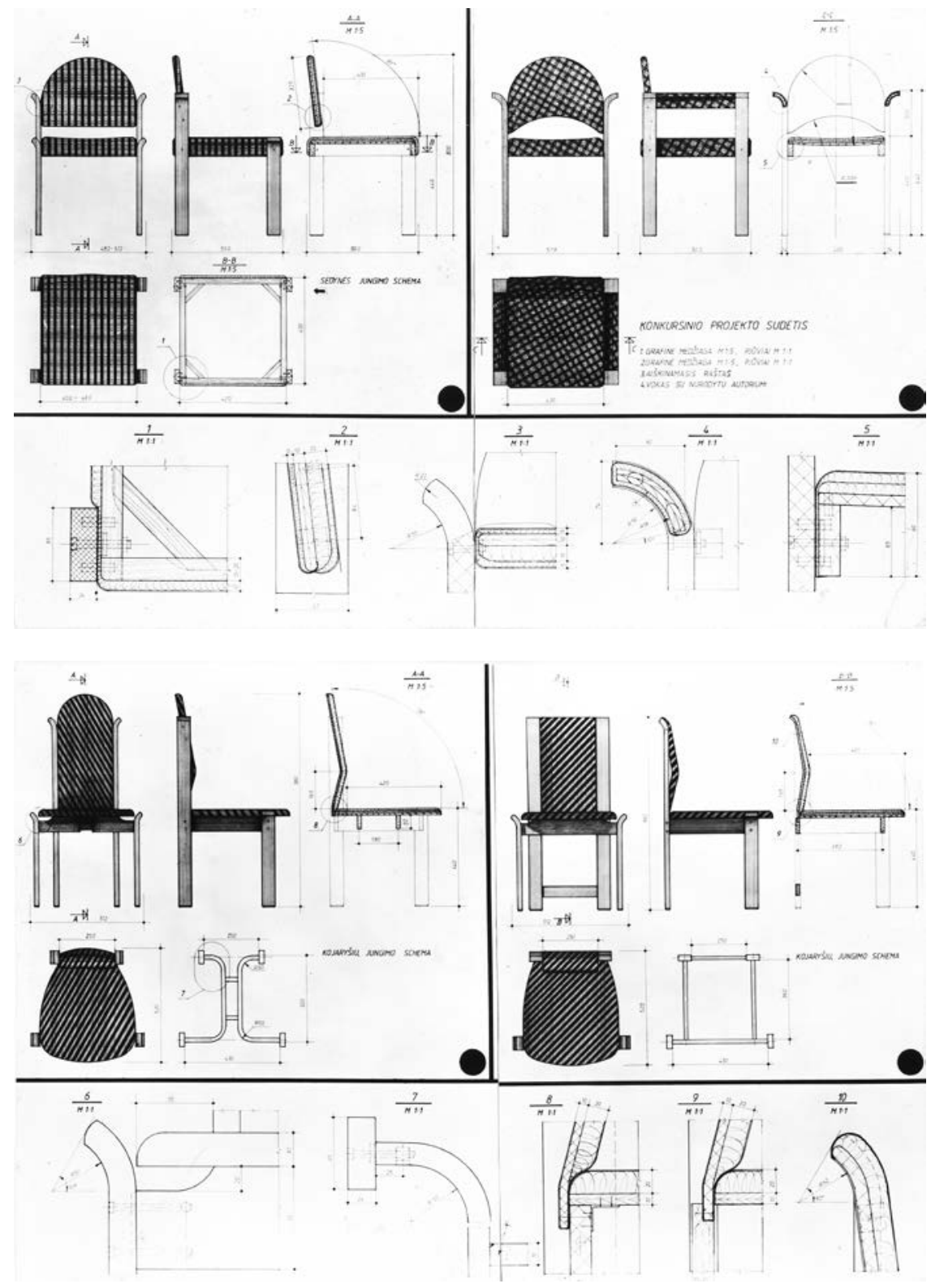

2.

Jolanta Bagdzevičienė, Konkursiniai kėdžių projektai, 1978-1979, nuotrauka iš asmeninio J. Bagdzevičienès archyvo
Jolanta Bagdzevičienè, Chair design proposals for competitions, 1978-1979, photo courtesy of Jolanta Bagdzevičienè 
nestovès be kojų, taip pat ir medžiagų atsparumo, kitais aspektais. “9 Architektès išsilavinimas pravertè dar ir todèl, kad Beiga, Baldų PKB direktoriaus pavaduotojas baldų ir interjero projektavimo reikalams, nesirinko darbuotojų be architektūrinio mąstymo. Pasak Bagdzevičienės:

\footnotetext{
Yra sričių, kuriose dailininkai neapsieina be dizainerių, architektų. Nors išimtys patvirtina taisyklę, dažniausiai pats dailininkas negali parodoje išeksponuoti savo kūrinių, o skulptorius pastatyti viešojoje erdvėje skulptūros. Dailininkas mato savo darbus, o ne erdvę, kurioje jie turi atsirasti. Baldų projektavimas ypač suaugęs su erdve, konkrečiais objektais, kuriems jie projektuojami, todèl V. Beiga ir ieškojo bei kvietė dirbti ị Baldų PKB projektuotojus, turinčius erdvės pojūtị. ${ }^{10}$
}

Nors patirties nebuvo daug, baldus kurti Bagdzevičienė pradėjo su dideliu entuziazmu. Tai matyti iš jos Baldų PKB sukurtų pirmụjų projektų. Vienas jų - tais laikais buvo labai neịprastas - pusapvalių, modulinių spintu projektas, kurtas biure vykusiam vietiniam konkursui. Kitam vietiniam Baldų PKB konkursui dizainerė suprojektavo kėdes, kurios taip pat neatitiko to meto minimalizuoto dizaino tendencijų [2 il.].

\section{Projektai iki 1990-ujuc}

Bagdzevičienė pateko i̇ Baldų PKB buitinių baldų projektavimo skyrių, tačiau kūrẻ baldus ir viešosioms erdvėms, projektavo ịvairios paskirties korpusinius baldus, kėdes. Nors biure buvo du skyriai - buitinių ir visuomeninių baldų projektavimo, pasak dizainerès, griežto pasiskirstymo nebuvo, projektuotojai galèjo dirbti ir vienus, ir kitus darbus ${ }^{11}$. Be šių projektų, Bagdzevičienės Baldų PKB pavedimu dalyvavo meno tarybose, prisidejjo prie valstybinio standarto (GOST) kūrimo. Minètini etapo iki 1990-űju jos projektai - baldai LSSR liaudies ūkio pasiekimų parodų rūmams (dab. Lietuvos parodų ir kongresų centras LITEXPO; toliau - LŪPP, Liaudies ūkio pasiekimų paroda), metalinès kėdès valgykloms, „,norvegiškos" kẻdès modifikacijos.

Baldai LŪPP rūmams (1980) buvo pirmasis daug atsakomybės ir išmonès pareikalavęs Bagdzevičienės projektas Baldų PKB [3, 4 il.]. Kurdama baldus ji bendravo, derino projektą su rūmų architektu Edmundu

9 Iš autorès pokalbio su Bagdzevičiene, 201812 13. Pokalbio ịrašas saugomas asmeniniame straipsnio autorès archyve.

10 Ibid. Dauguma pagrindinių Baldų PKB dizainerių turejjo architekto išsilavinimą.

11 Ibid. 


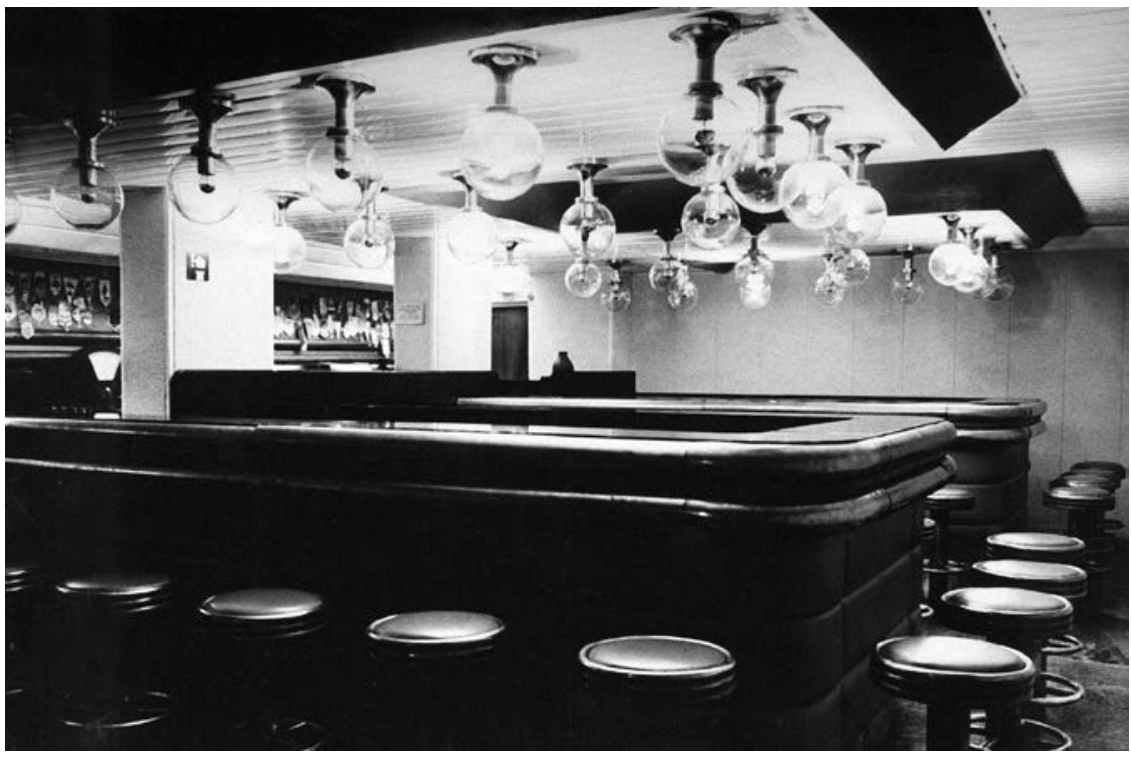

3

Jolanta Bagdzevičienè, Baras LSSR liaudies ūkio pasiekimų parodų rūmuose (dab. Lietuvos parodų ir kongresu centras LITEXPO), 1980, nuotrauka iš asmeninio J. Bagdzevičienès archyvo
Jolanta Bagdzevičienè, Bar at the Exhibition Palace of Achievements of National Economy of the LSSR (today, Vilnius Exhibition Palace, Litexpo), 1980, photo courtesy of Jolanta Bagdzevičienè

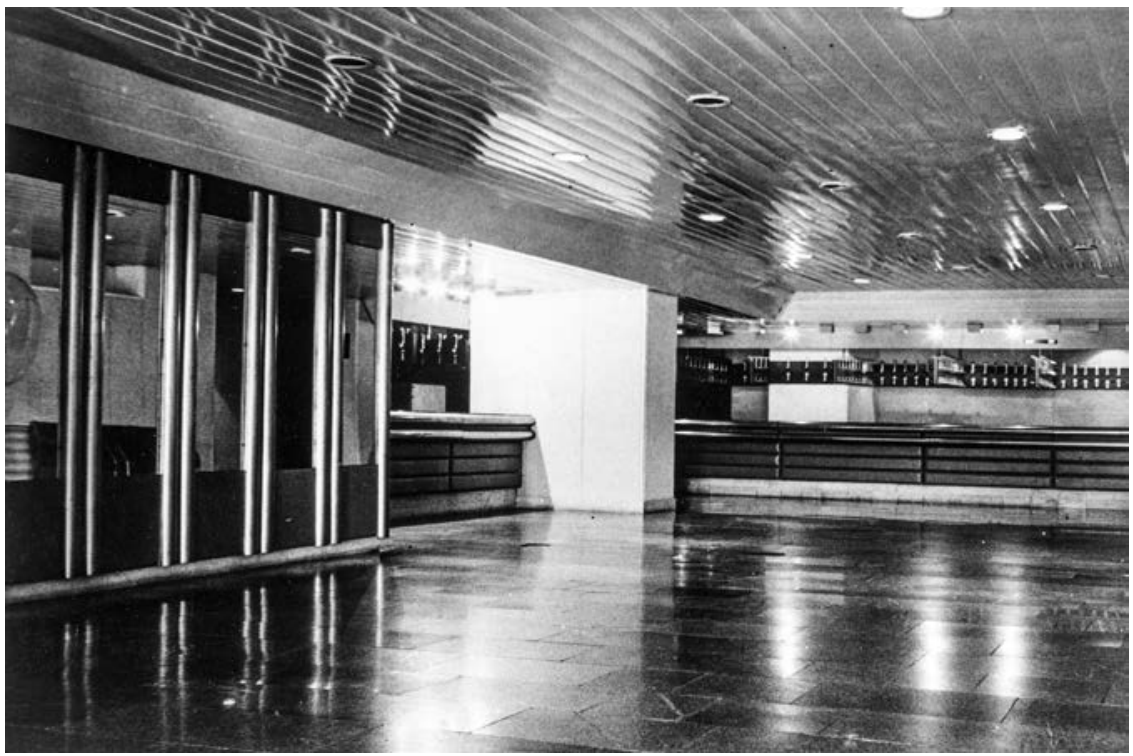

4.

Jolanta Bagdzevičienè, Drabužinė LSSR liaudies ūkio pasiekimų parodų rūmuose, konstruktorius Antanas Kindurys, gamintojas Baldų PKB, 1980, nuotrauka iš asmeninio J. Bagdzevičienès archyvo
Jolanta Bagdzevičienė, Cloakroom at the Exhibition Palace of Achievements of National Economy of the LSSR, constructor Antanas Kindurys, produced by BFDC, 1980, photo courtesy of Jolanta Bagdzevičienė 
Stasiuliu, kuris jai buvo pateikęs projekto schemą su numatytu erdvių zonavimu, apšvietimu. Bagdzevičienè projektavo rūmų kasą, rūbinę ir išskirtinị, išraiškingą barą. Dizaino stiliu ji suvokè kaip visuminị, siejantị baldus ir architektūrą. Erdvėse esantys metaliniai porankiai buvo panaudoti ir baro baldams. Jie driekėsi baro stalų kraštais, buvo integruoti ị kitus baro baldus. Iš vamzdžių buvo pagamintos baro kėdžių kojos, trys eilès mažesnio skersmens žalvario spalvos vamzdelių juosè raudonas šių kẻdžiu sėdynes, jie buvo naudojami ir kojoms pasidèti kèdès apačioje. $2017 \mathrm{~m}$. centriniai parodų rūmai buvo rekonstruoti ${ }^{12}$. Bagdzevičienès projektuoti baldai iki mūsų dienų neišliko, greičiausiai neittraukus jų i kultūros vertybių registro aprašymą ${ }^{13}$. Kitaip nei architektūra, architektūros elementai, pastate esantis Algirdo Dovydèno vitražas (1990), unikalūs specialiai rūmams sukurti baldai nepripažinti svarbiu Lietuvos dizaino istorijos paveldu.

9 deš. viduryje Bagdzevičienei teko Baldų PKB gautas užsakymas suprojektuoti tipinius baldus visos Sovietų Sajungos visuomeninio maitinimo ịstaigoms. Iš SSRS miško ir popieriaus pramonės ministerijos (rus. Министерство лесной и бумажной промышленности (ССР) atkeliavusią idėją - visuotinę visų milžiniškos sovietų imperijos maitinimo ịstaigų baldų unifikacija - Bagdzevičienė pavadino „sajungine utopija“"14, kuriai, akivaizdu, buvo lemta žlugti. Žvelgiant iš šių dienų pozicijų, sunku suprasti tokios idejjos tikslingumą, ypač turint minty, kad Lietuvoje restoranai, kavinès ir valgyklos buvo nedidelès, dažnai - kamerinès patalpos. Didžiujų sovietiniu miestų maitinimo ịstaigos labai skyrèsi nuo lietuviškų. Dizainerė prisimena: „isivaizduokite restoraną Maskvoje, kai eidavome pietauti, nematydavome jo pabaigos. Ten kitas mastelis, mes tik ịsivaizduojame, kad restoranas gali būti mažutis ir jaukus kaip užsienyje. “15 Šiuo atveju galbūt galima bandyti suprasti tokios idèjos pagrindą - juk baldų reikèjo labai daug.

Idèja pagaminti unifikuotus baldus maitinimo įstaigoms buvo parengta įgyvendinti, vyko paruošiamasis darbas, suprojektuoti ir gaminti baldai. Šis didelis projektas pareikalavo daug jègų ir laiko. Bagdzevičienė dažnai vykdavo ị komandiruotes - ị Leningradą (dab. Sant Peterburgas), Rostovą

12 Autoriai - Edmundas Stasiulis, Rolandas Palekas, Bartas Puzonas, Alma Palekienè, Dalia Uogintė, Radvilè Samackaitė, Karolina Burbaitė. „Centrinių „Litexpo“ rūmų rekonstrukcija“, Paleko architektu studija, http://palekas.lt/projektai/visuomeniniai/1-asis-litexpo-pavilijonas/.

13 „Vilniaus parodų rūmai“, Kultūros vertybių registras, https://kvr.kpd.lt/\#/static-heritagesearch.

14 Bagdzevičienė, „Visus projektus koreguoja gyvenimas“, 210.

15 Iš autorès pokalbio su Bagdzevičiene, 20181213. 
134
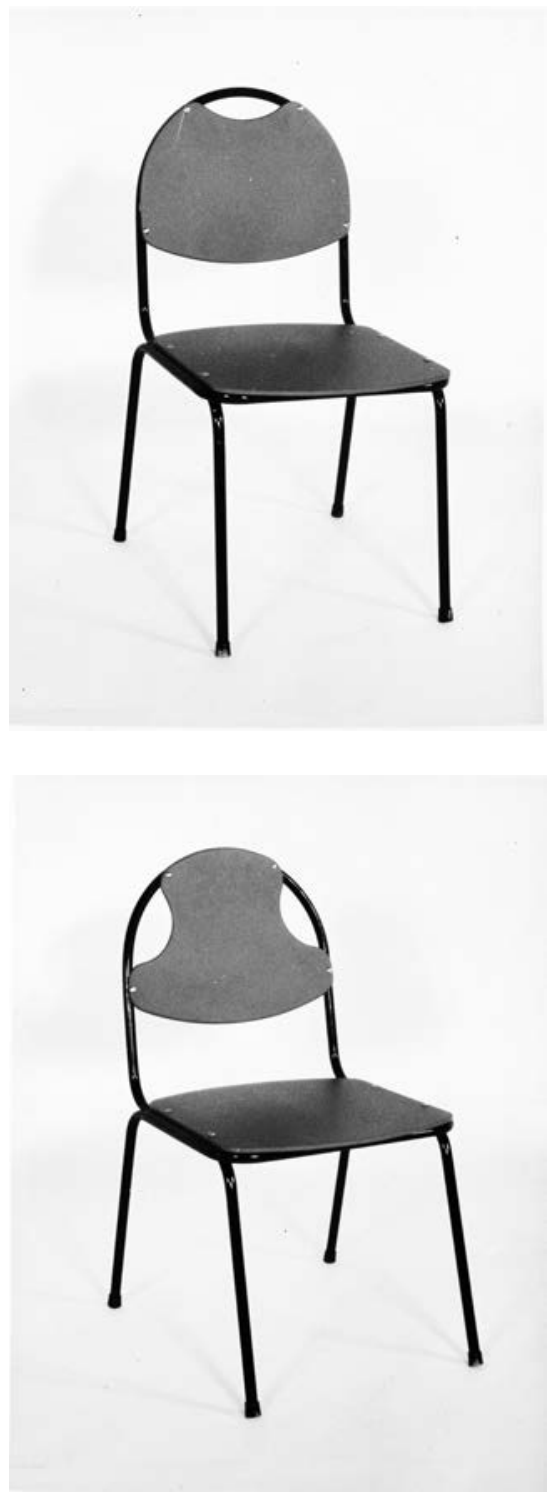

5.

Jolanta Bagdzevičienė, Eksperimentinių kẻdžių valgykloms serija (proj. Nr. 01/5270-04, 01/5270$05,01 / 5270-06), 1987$, nuotrauka iš asmeninio J. Bagdzevičienès archyvo

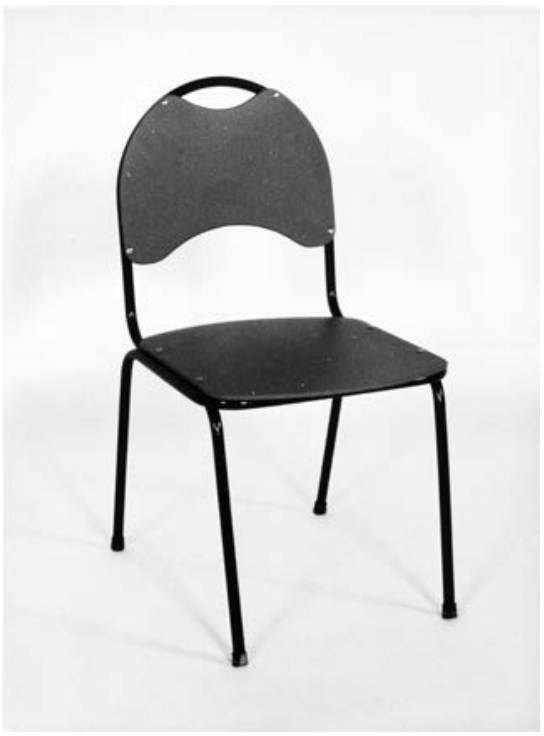

Jolanta Bagdzevičienė, Series of experimental chairs for canteens (project No. 01/5270-04, 01/527005, 01/5270-06), 1987, photo courtesy of Jolanta Bagdzevičienè 


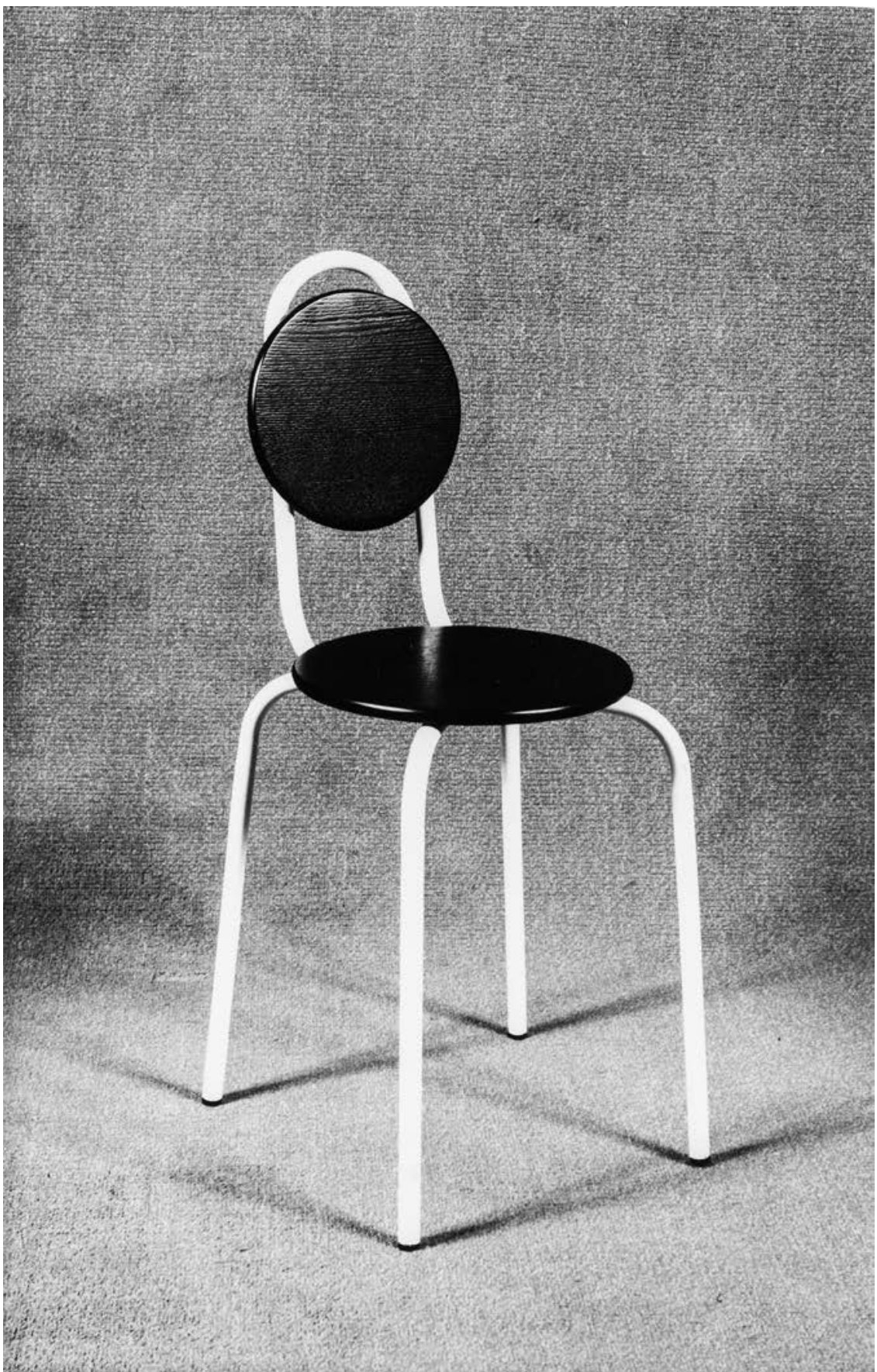

6.

Jolanta Bagdzevičienė, Eksperimentinė kèdė mokyklų valgykloms, 1987, nuotrauka iš asmeninio J. Bagdzevičienès archyvo
Jolanta Bagdzevičienè, Experimental chair for school canteens, 1987, photo courtesy of Jolanta Bagdzevičienè 
prie Dono, Maskvą, Donecką, dalyvaudavo meno tarybose, lankydavo gamintojus. Meno tarybos, pasak jos, vyko tose įmonėse, kuriose baldai buvo gaminami, i jas suvažiuodavo atstovai ir iš kitų respublikų. Baldai gaminti ir įkalinimo įstaigose. Baldų maitinimo i̦staigoms asortimentas buvo labai platus - visa reikalinga ịranga. Bagdzevičienès projektuotoms metalinèms valgyklų kėdèms 1989 m. suteikti pramoninio pavyzdžio autoriniai liudijimai. Kèdès ir jų variantai buvo sukurti kiek anksčiau - 1987-aisiais [5, 6 il.].

1989 m. Bagdzevičienė gavo dar keturių kėdžių pramoninio pavyzdžio autorinius liudijimus. Šikart ne iš metalo, o lenktų klijuoto medžio lukšto elementų. Šio projekto priešistorè veda ị Šiaulių baldų gamybinị susivienijimą „Venta“, kuris sovietmečiu specializavosi gaminti kẻdes. Itin masiškai čia gaminta savitos konstrukcijos „norvegiška“ kèdè (proj. nr. 849). Jos, pozicionuotos kaip darbo kèdè, prototipas greičiausiai buvo atsigabentas iš Skandinavijos ir pritaikytas vietinei gamybai. Bagdzevičienè padèjo kurti naujus „norvegiškos“ kèdès projektus, nes reikèjo pakeisti gaminị. Todèl pageidauta, kad išliktų lenktai klijuotos konstrukcijos dalys su kiauru sujungimu. Bagdzevičienės sukurtos kėdès iš lenktai klijuotų elementų (proj. nr. 849-02, 849-03, 849-04, 849-05) buvo su siauresnèmis ir platesnèmis, kieta arba paminkštinta, tiesia arba lenkta nugarèle ir sèdyne ${ }^{16}$ [7-10 il.].

\section{Projektai nuo 1990-ujų}

Atsivèrus sienoms, apsinuogino technologiniai, estetiniai Vakaru ir posovietinių šalių skirtumai. Bagdzevičienè prisimena, kad to atotrūkio būta skaudaus: ,prieš pat atkuriant Lietuvos nepriklausomybę, 1989 m., buvau parodoje Paryžiuje. Ten pamačiau dalykų, kurių pas mus nebuvo - apie tai kol kas galejome tik pasvajoti."17

Atkūrus Lietuvos nepriklausomybę, prasidèjo kardinalių permainų metas visose srityse. Sovietini ir atkurtos Lietuvos nepriklausomybès laikotarpius skyrè dizaino objektų sukūrimo aplinkybės - užsakovas, vartotojas, estetiniai orientyrai. Baldų PKB, sovietiniu laikotarpiu pagrindinè dizaino institucija, sunyko. Nyko ir buvusi dizaino sukūrimo bei gamybos grandinè. Gamintojai galèjo gaminti pagal poreikị, savo nuožiūra, projektus rinkosi be meno tarybų, žvalgèsi ị užsienị. Laisvos rinkos specifika, buvusių

16 Plačiau apie „norvegišką“ kėdę ir Bagdzevičienès projektus žr.: Janulevičiūtė, 10 kẻdžiu: Lietuvos dizaino naratyvai, 412-421.

17 Iš autorès pokalbio su Bagdzevičiene, 20181213. 


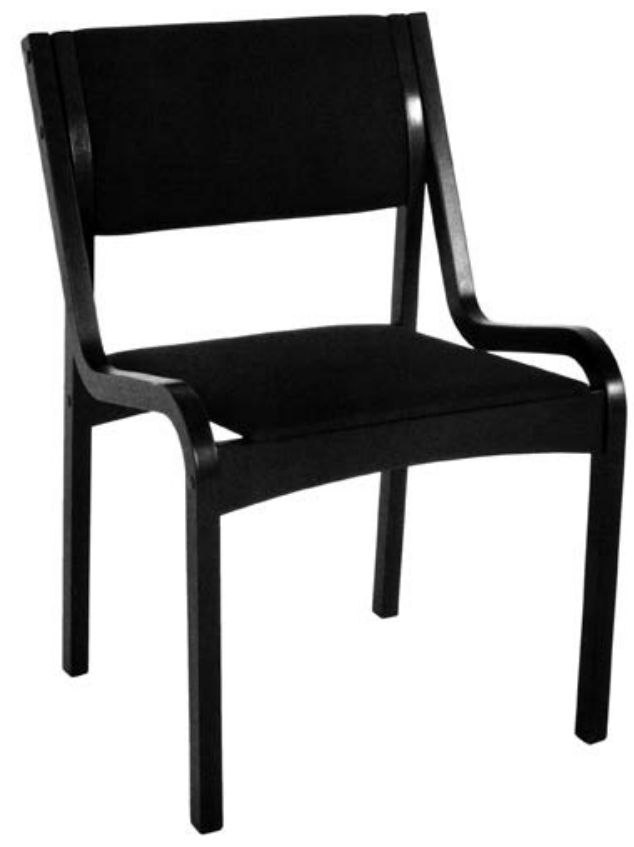

7.

Jolanta Bagdzevičienè, Darbo kèdè (proj. Nr. 849-02), 1989, nuotrauka iš asmeninio J. Bagdzevičienės archyvo

Jolanta Bagdzevičienė, Work chair (project No. 849-02),

1989 , photo courtesy of Jolanta Bagdzevičienè

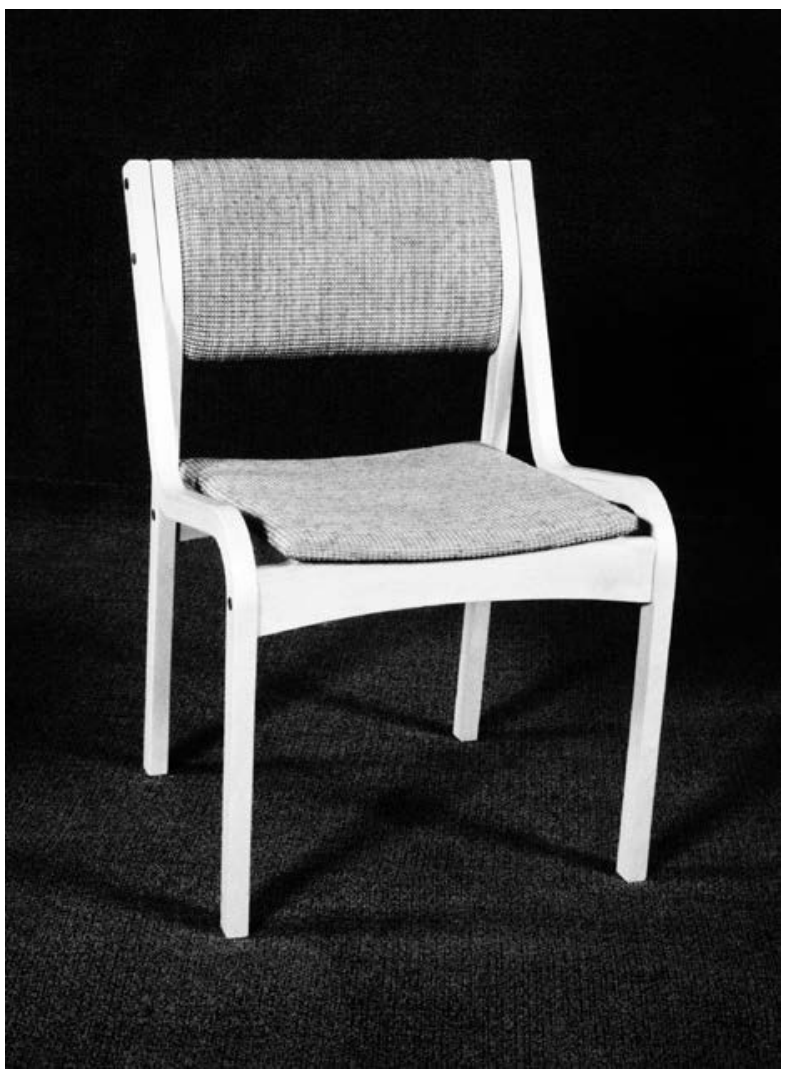

8.

Jolanta Bagdzevičienė, Darbo kèdè (proj. Nr. 849-03), 1989, nuotrauka iš asmeninio J. Bagdzevičienès archyvo

Jolanta Bagdzevičienė, Work chair (project No. 849-03), 1989, photo courtesy of Jolanta Bagdzevičienè 

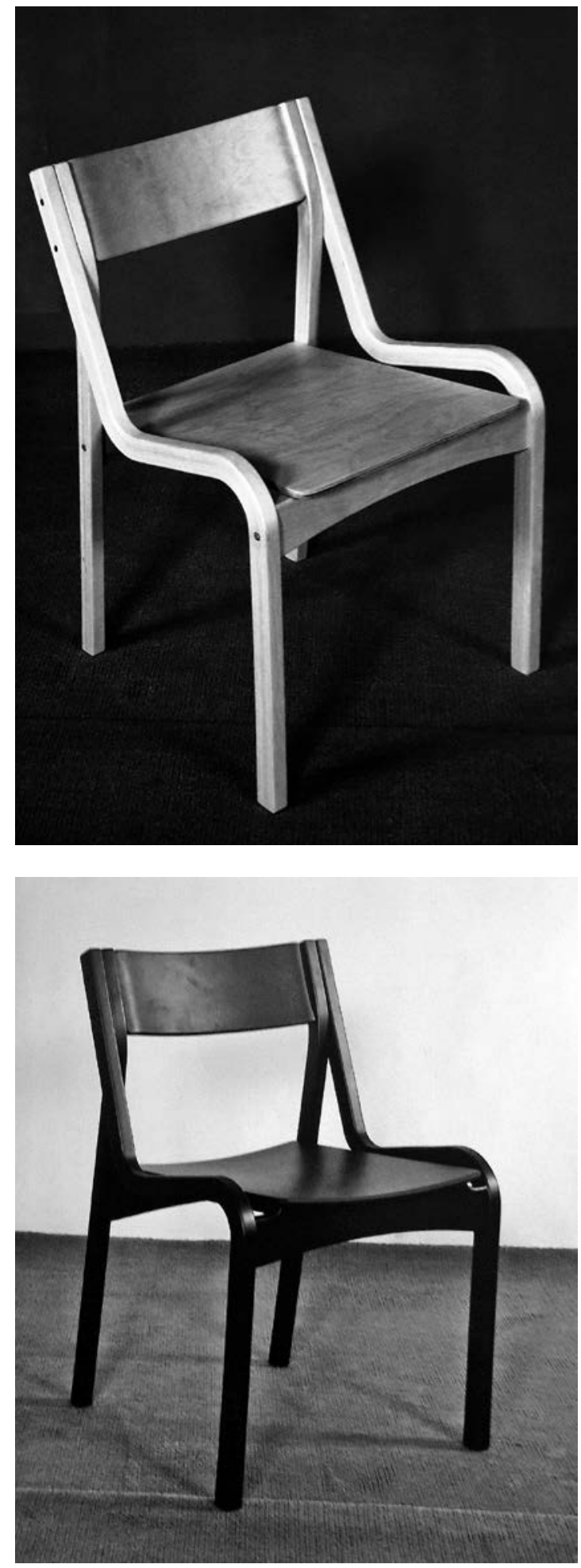

9.

Jolanta Bagdzevičienė, Darbo kèdè (proj. Nr. 849-04), 1989, nuotrauka iš asmeninio J. Bagdzevičienès archyvo

Jolanta Bagdzevičienè, Work chair (project No. 849-04), 1989, photo courtesy of Jolanta Bagdzevičienè

10.

Jolanta Bagdzevičienė, Darbo kèdè (proj. Nr. 849-05), 1989, nuotrauka iš asmeninio J. Bagdzevičienès archyvo

Jolanta Bagdzevičienè, Work chair (project No. 849-05), 1989, photo courtesy of Jolanta Bagdzevičienè 
valstybiniu gamybos įmonių privatizavimas vertė dizainerius ieškoti naujų bendradarbiavimo su gamintojais būdų, vietoj kolektyvinio, institucionalizuoto darbo projektavimo biuruose vykdyti verslininkų užsakymus arba pradèti savo verslą kuriant dizaino studijas.

Itin dideliu išmėginimu tapo pirmasis Lietuvos nepriklausomybės atkūrimo dešimtmetis, komplikuotas dèl Sovietų Sajungos vykdytos Lietuvos ekonominės blokados ir jos pasekmių. Kaip ir kitu radikalių permainu pradžioje, šis laikas buvo kupinas vilčiu. Tikètasi, kad, kuriantis naujiems gamintojų ir dizaino kūrẻjų darbo santykiams, bus atrasta naujų dizaino idejjų realizavimo galimybių. Tačiau dizaino atsinaujinimo procesas nevyko sklandžiai. Gretinant sovietmečiu ir atkurtos Lietuvos nepriklausomybès pradžioje buvusias dizainerių ir gamintojų arba užsakovų pozicijas, galima pastebèti, kad įvyko paradoksaliu pervartų. Jei sovietmečiu, apskritai tariant, dizaineris turèjo lemiamą balsą spręsdamas estetinius klausimus, atkūrus nepriklausomybę, atsirado nepageidaujamų laisvosios rinkos efektų-užsakovo diktato, pataikavimo vartotojo skoniui ir netvarios mados tendencijoms, neprofesionalios veiklos dizaino srityje. Pastaroji problema kèlè daug rūpesčių, kadangi itin greitai pajausta, kad dizaino užsakymai yra pelningi, projektuoti pradèjo neprofesionalūs, patirties neturintys, bet kompiuterines programas ịvaldę asmenys. Atkūrus Lietuvos nepriklausomybę, dizaineriams reikèjo išsikovoti gero ir profesionalaus dizaino pozicijas.

Bagdzevičienè, kaip ir kiti Lietuvos dizaino lauko dalyviai, susidūrè su šiais kintančio laikotarpio iššūkiais. Baldụ PKB ji dirbo iki pat nepriklausomybès atkūrimo 1990 m., o vẻliau, kaip ir dalis kitų buvusių Baldų PDB darbuotojų, buvo įtraukta ị pereinamojo laikotarpio biuro reorganizavimų, pertvarkų peripetijas. Iki 1998 m. Bagdzevičienė dirbo AB „Skraja“ (dab. Baldų ir verslo centras „Skraja“). Šios bendrovès, ikurtos vietoj Baldų $\mathrm{PKB}$, veikla siejama su biuro ịkūrimo data, ji ir prisistato kaip biuro ịpèdinė: „Skraja“ savo veiklą pradejjo 1957 m., kaip Baldų pramonės projektavimo-konstravimo biuras.“18 1999 m. „Skraja“ ikkūrẻ Baldų ir verslo centrą, atsisakè ir baldų projektavimo, ir jų gamybos ${ }^{19}$. Paskutiniais XX a. - XXI a. 1 deš. Bagdzevičienè dirbo Vilniaus baldų kombinate (dab. AB ,Vilniaus baldai“), SBA balduose, UAB „Baldora“. 


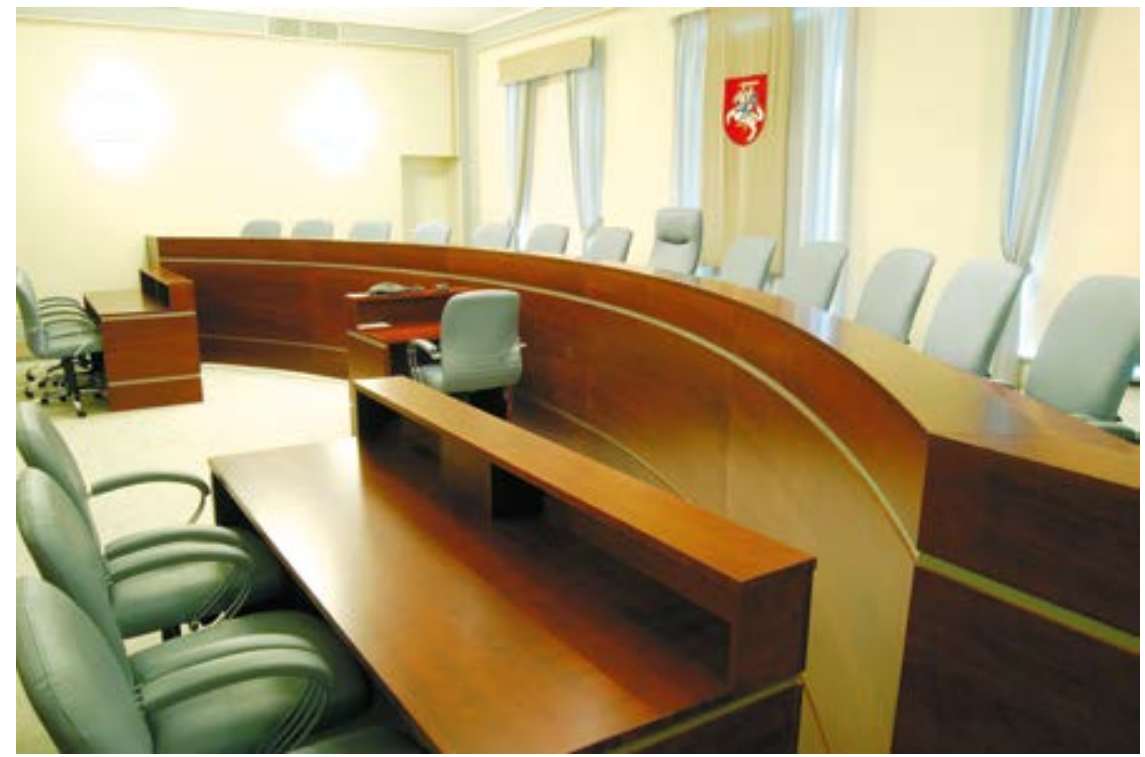

11.

Jolanta Bagdzevičienė, LR vyriausiojo administracinio teismo didžiosios posèdžių salès interjeras, 2006, nuotrauka iš asmeninio J. Bagdzevičienès archyvo
Jolanta Bagdzevičienè, Interior of the great conference hall of the Higher Administrative Court of the Republic of Lithuania, 2006, photo courtesy of Jolanta Bagdzevičienè

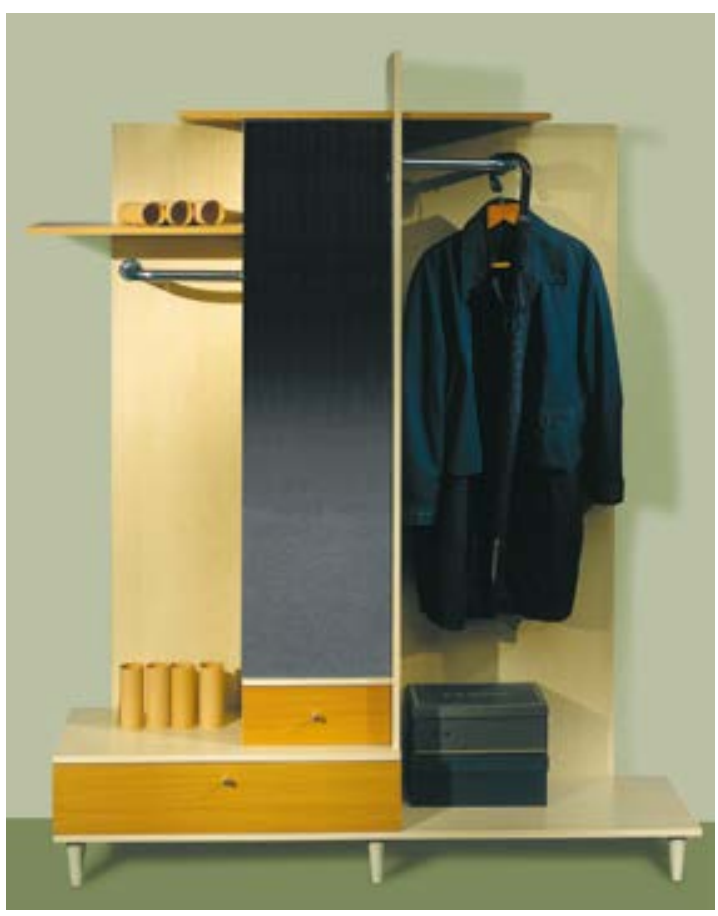

12.

Jolanta Bagdzevičienè,

Prieškambaris „Rikis“, 1999,

nuotrauka iš asmeninio

J. Bagdzevičienès archyvo

Jolanta Bagdzevičienė, Hallway

furniture set Rikis, 1999,

photo courtesy of Jolanta

Bagdzevičienè 


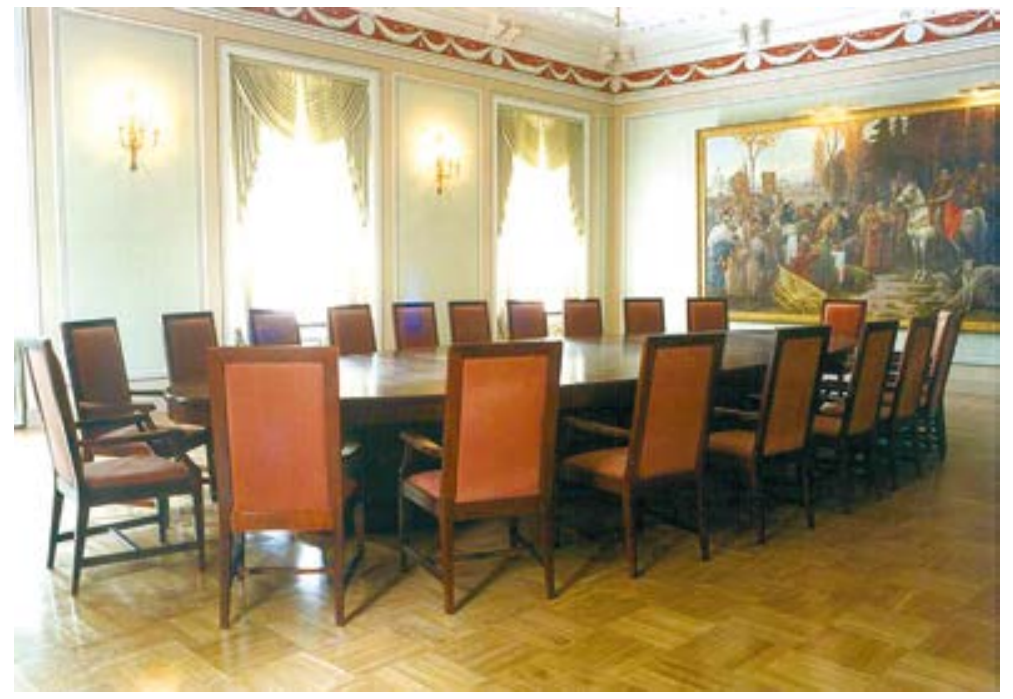

13

Jolanta Bagdzevičienè, Pasitarimų stalas

LR Prezidentūros Patarejjų (Posèdžių) salèje, konstruktorius Kazimieras Murauskas, 1997, nuotrauka iš asmeninio J. Bagdzevičienès archyvo
Jolanta Bagdzevičienè, Meeting table at the Counsellors (Meeting) Hall of the Presidential Office of the Republic of Lithuania, constructor Kazimietras Murauskas, 1997, photo courtesy of Jolanta Bagdzevičienè

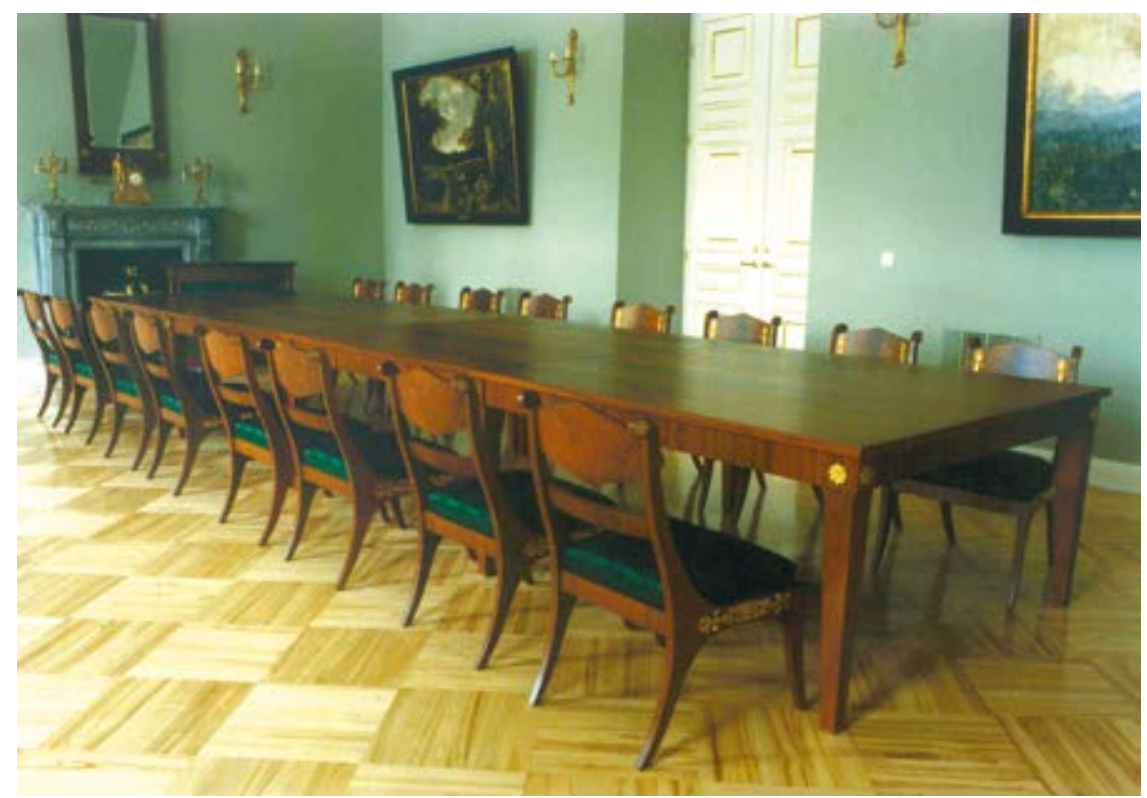

14

Jolanta Bagdzevičienè, Pietų stalas LR Prezidentūros valgomajame, konstruktorius Kazimieras Murauskas, 1997, nuotrauka iš asmeninio J. Bagdzevičienès archyvo
Jolanta Bagdzevičienė, Dinner table in the dining room of the Presidential Office of the Republic of Lithuania, constructor Kazimieras Murauskas, 1997, photo courtesy of Jolanta Bagdzevičienè 


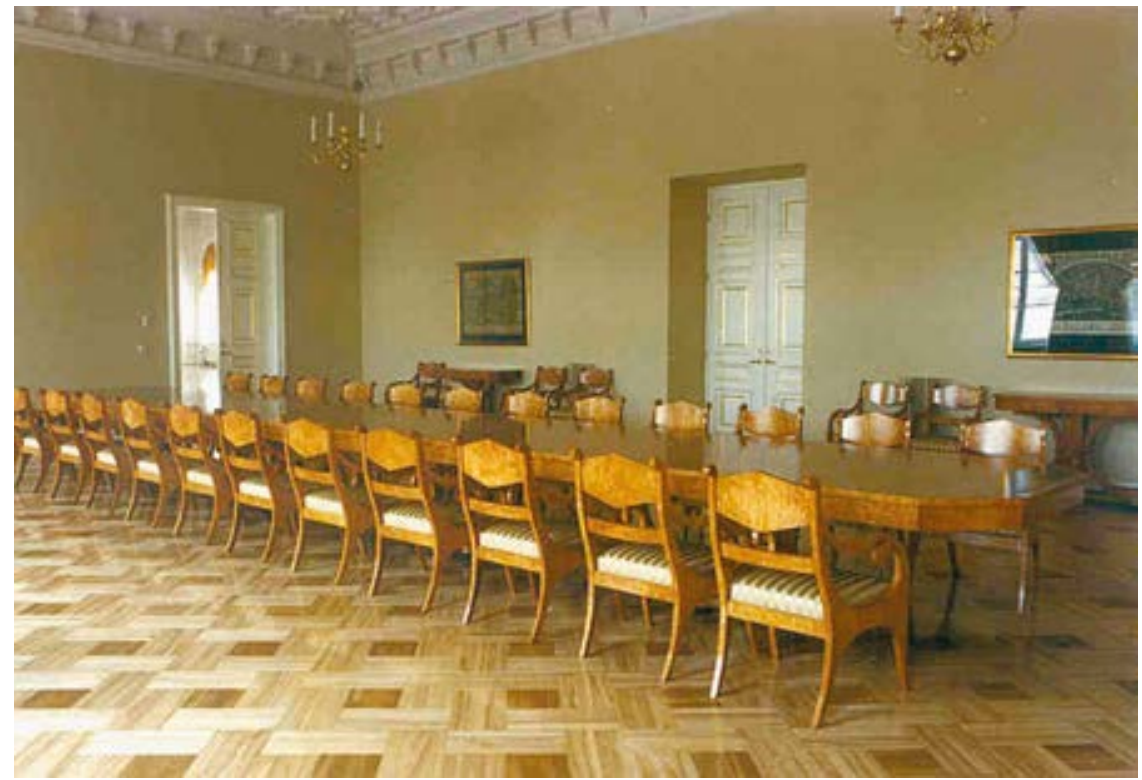

Jolanta Bagdzevičienè, Pasitarimụ stalas LR Prezidentūros Derybų salejje, konstruktorius Kazimieras Murauskas, gamintojas AB „Skraja“, 1997, nuotrauka iš asmeninio $\mathrm{J}$. Bagdzevičienès archyvo
Jolanta Bagdzevičienè, Meeting table in the meeting hall of the Presidential Office of the Republic of Lithuania, constructor Kazimieras Murauskas, producer AB Skraja, 1997, photo courtesy of Jolanta Bagdzevičienẻ

Po Lietuvos nepriklausomybės atkūrimo Bagdzevičienė vykdė įvairių institucijų užsakymus. Projektavo baldus Žemės ūkio banko Vilniaus filialo operacijų salei ir administracinėms patalpoms, Lietuvos banko kabinetams, valgyklai, posėdžių salėms ${ }^{20}$, ambasadoms (Ukrainos ambasadai Vilniuje, Lietuvos Respublikos ambasadoms Varšuvoje, Taline, Hagoje), JAV kultūros meno centrui Vilniuje (kartu su Mantu Lesausku) ir kt., sukūrè baldų ịstaigoms ir buitinių baldų komplektų („Nova“, „Mozaika“, „Rido“, „Arija“ ir kt.) [11, 12 il.].

1998 m. Bagdzevičienei už Lietuvos Respublikos Prezidentūros rūmams suprojektuotus baldus buvo ịteikta Algirdo Mykolo Brazausko padèka. Šị projektą ji vykdè 1996-1998 m., jo apimtis didelè - baldai Prezidento posėdžių, Derybų, Patarèjų posėdžių salèms, kanceliarijai, valgomajam, priimamajam ir kitoms patalpoms [13, 14 il.]. Derybų salei dizainerè 
suprojektavo prabangų kareliško beržo stalą su juodmedžio juostele [15 il.], kanceliarijoje - visus baldus. Išskirtiniai yra LR Prezidentūros Spaudos konferencijų salès baldai [16 il.]. Konferencijų salès interjeras sukurtas komponuojant zonas - pranešimų, konferencijos dalyvių ir vertëjų. Pranešimų zonai Bagdzevičienė sukūrè tamsų, tokios pačios kaip kẻdės spalvos, masyvų stalą, kuris vẻliau buvo nudažytas šviesiai. Vertėjams salės gale numatytos specialios kabinos. Kèdès sustatytos eilèmis. Bagdzevičienès asmeniniame archyve yra atlenkiamos kėdès brěžinys, jos konstruktorè - Elvyra Atkočiūtè. 42 sujungiamos, viena prie kitos montuojamos raudonmedžio kèdès salei buvo pagamintos „Skrajoje“, tuometinėje Bagdzevičienės darbovietėje. Projekte autorè buvo numačiusi mažesni pirmoje eilèje esančiu kèdžių kiekị. Jos turèjo būti keturios, kad pagal tuometinius poreikius greta tilptų filmavimo kameros. Lietuvos dizainerès specialiai LR Prezidentūrai sukurti baldai - unikalūs, vienetiniai. Tai - neserijinè gamyba ir ne interjero sukūrimas parenkant esamus masinès gamybos pavyzdžius. Prezidentūros baldams būdinga saikinga minimalistinè estetika. Postmodernūs sprendimai, pasak Bagdzevičienès, reprezentacinei erdvei netiko.

\section{Išvados}

Ir sovietiniu, ir atkurtos Lietuvos nepriklausomybės laikotarpiu Bagdzevičienès kūryba buvo intensyvi. Sovietmečiu ji sukūrè reikšmingu projektų - unikalių, skirtų konkrečioms erdvėms, taip pat ir masinės gamybos baldu. Atkurtos Lietuvos nepriklausomybès laikotarpiu jos veikla plètota atsižvelgiant $i$ kintančius poreikius ir gamybos technologijas. Keitèsi ir dizainerès braižas, tačiau itin radikalių eksperimentų nebuvo. Autorè išlaikė saikingą, elegantišką meninę raišką. Baldų gamintojų užsakymu jos projektuoti buitinès paskirties baldai atitikto naujus vartotojų lūkesčius, buvo šiuolaikiški ir atspindèjo, kaip sparčiai reaguota ị radikalius socialinius, ekonominius ir kultūrinius pokyčius. Ji turejjo gerą dizainerès reputaciją, kuriai patikèti atsakingi viešojo sektoriaus užsakymai - suprojektuoti reprezentacinių ir administracinių erdvių baldus.

Bagdzevičienès sovietmečiu sukurti unikalūs projektai neišliko, o šiuolaikiniai dažnai keičiami be autorès žinios. Ši situacija nèra išimtis. 

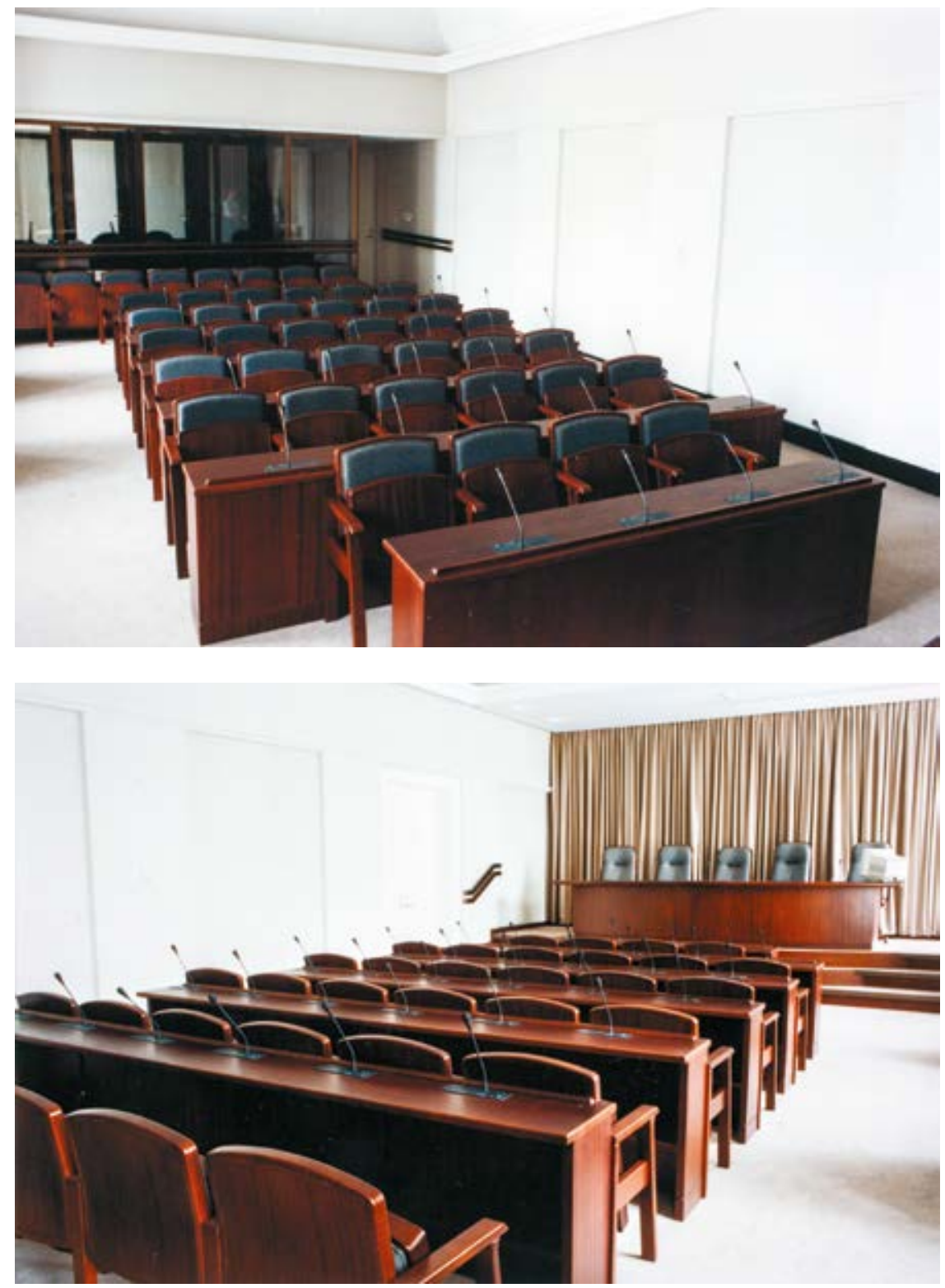

16.

Jolanta Bagdzevičienė, LR Prezidentūros Spaudos konferencijų salės baldai, konstruktorè Elvyra

Atkočiūtè, gamintojas AB „Skraja“, 1997, nuotrauka iš asmeninio J. Bagdzevičienės archyvo
Jolanta Bagdzevičienè, Furniture for the conference hall of the Presidential Office of the Republic of Lithuania, constructor Elvyra Atkočiùtè, producer $\mathrm{AB}$ Skraja,1997, photo courtesy of Jolanta Bagdzevičienė 
Nesant deramos dizaino palikimo apsaugos, Lietuvoje buvo sunaikinta daug svarbių mūsų dizainerių sukurtų interjerų ir specialiai pastariesiems sukurtų baldų. Tikètina, kad bus suprasta, jog reikètų saugoti ne tik nekilnojamąsias kultūros vertybes, bet ir atskirtus dizaino kūrinius dèl ju vertingujų savybių - kaip saugoma tapyba, skulptūra, vitražas ir kiti dailès kūriniai. Bagdzevičienès kūryba svarbi ir verta saugos įvairiais aspektais kaip sovietinio ir atkurtos Lietuvos nepriklausomybės laikotarpių istorinès atminties dokumentas, liudijantis socialinius, kultūrinius ir ekonominius pokyčius, dèl meninès vertès, reikšmingo indèlio ị Lietuvos dizaino istoriją.

\section{Gauta 20201005}




\section{Literatūra ir šaltiniai}

„Apie mus“. Skraja, žiūrèta 2020 m. rugpjūčio

11 d. http://www.businesscentre.lt/.

Bagdzevičienė, Jolanta. „Visus projektus

koreguoja gyvenimas“. In Lietuvišku baldu dizaino kūrèjai 1957-1990: Baldu projektavimo konstravimo biuras - profesionalios veiklos židinys. Sudarė Vytautas Beiga, Vilija Gerulaitienè ir Eugenijus Gūzas, 210-211. Vilnius: Mokslo ir enciklopediju leidybos centras, 2013.

Janulevičiūtè, Rasa. 10 kèdžiu: Lietuvos dizaino naratyvai. Vilnius: Vilniaus dailès akademijos leidykla, 2018.

Lietuvišku baldu dizaino kürëjai 195\%-1990: Baldu projektavimo konstravimo biuras profesionalios veiklos židinys. Sudarè Vytautas Beiga, Vilija Gerulaitienè ir Eugenijus Gūzas. Vilnius: Mokslo ir enciklopedijų leidybos centras, 2013.

Lietuvos banko rūmai Vilniuje. Teksto autorè Morta Baužienè. Vilnius: Lietuvos bankas, 2007.

Paleko architektų studija, žiūrèta $2020 \mathrm{~m}$. rugpjūčio $21 \mathrm{~d}$. http://palekas.lt/projektai/ visuomeniniai/1-asis-litexpo-pavilijonas/.

„Vilniaus parodų rūmai“. Kultūros vertybiu registras, žiūrèta 2020 rugpjūčio $21 \mathrm{~d}$. https:// kvr.kpd.lt/\#/static-heritage-search.

Броновицкая, Анна. „Бакминстер Фуллер (США, 1895-1983)“. In Музей современного искусства „Гараж“. Paskelbta 2017 m. gegužès $18 \mathrm{~d}$. https://www.youtube.com/watch? $\mathrm{v}=5 \mathrm{rXJAoOAEuk \& list}=$ PLRSwFqRepg4FLjYNn77DKTROti-0kjZ_e\&index=7. 


\title{
Summary
}

\section{Design by Jolanta Bagdzevičienè in the Context of Two Periods}

\author{
Rasa Janulevičiūtè
}

Keywords: design, Soviet period, restored independence of Lithuania, Bureau of Furniture Design and Construction, Architects' Union.

Jolanta Bagdzevičienè is one of the most prominent Lithuanian designers, a member of the Architects' Union who won acclaim in various design competitions and exhibitions "Lithuanian Furniture", "Furniture", and the competition of "Product of the Year" held by the Lithuanian Confederation of Industrialists. Her creative career spans two periods - Soviet and newly independent Lithuania. Bagdzevičienė worked in exhibition design, designed furniture for home and public interiors.

Bagdzevičienè's professional career began in the early 1970s. In 1972, she started studying architecture at the Faculty of Architecture of the Vilnius Civil Engineering Institute (VISI; today, VGTU - Vilnius Gediminas Technical University). In 1977, she got a job at the leading institution of furniture design in Lithuania in the Soviet period - the Bureau of Furniture Design and Construction (hereinafter BFDC), where top Lithuanian designers were employed.

At the BFDC, Bagdzevičienè worked at the Department of Home Furniture Design, and also designed furniture for public spaces, carcass furniture of various functions and chairs, took part in artistic councils, and was involved in developing the GOST standard. Bagdzevičienè's projects created in the period before 1990 - furniture for the Palace of Achievements of National Economy of the LSSR (today, Vilnius Exhibition Palace, Litexpo), metal chairs for canteens, and modifications of the "Norwegian chair" should be mentioned. 
The restoration of independence in Lithuania brought changes to all fields of life. The BFDC was dissolved. The former design creation and production chain also fell apart. Bagdzevičiene worked in the BFDC up until the restoration of independence in 1990, and later, like part of other former employees, was involved in the restructuring of the BFDC in the period of transition. Until 1998, Bagdzevičienè worked in the joint-stock company Skraja (today, AB Skraja, a furniture and industry centre), and later, at the Vilnius Furniture Production Company (today, AB Vilniaus baldai), SBA baldai company, and UAB Baldora. After the restoration of independence, Bagdzevičienè worked by commission for various institutions. She designed furniture for the Presidential Palace of the Republic of Lithuania, the customer service hall and administrative premises of the Vilnius branch of the Bank of Agriculture, offices, the canteen and conference halls of the Bank of Lithuania, and various embassies (the Embassy of Ukraine to Vilnius, the embassies of the Republic of Lithuania to Warsaw, Tallinn, and the Hague), designed furniture for offices and home furniture sets. 